\title{
Functional characterization and evolution of PTH/PTHrP receptors: insights from the chicken
}

\author{
Pedro LC Pinheiro ${ }^{\dagger}$, João CR Cardoso* ${ }^{* \dagger}$, Deborah M Power and Adelino V M Canário
}

\begin{abstract}
Background: The parathyroid hormone (PTH)-family consists of a group of structurally related factors that regulate calcium and bone homeostasis and are also involved in development of organs such as the heart, mammary gland and immune system. They interact with specific members of family 2 B1 G-protein coupled receptors (GPCRs), which have been characterised in teleosts and mammals. Two PTH/PTHrP receptors, PTH1R and PTH2R exist in mammals and in teleost fish a further receptor PTH3R has also been identified. Recently in chicken, PTH-family members involved in calcium transport were characterized and specific PTHRs are suggested to exist although they have not yet been isolated or functionally characterized. The aim of this study is to further explore the evolution and function of the vertebrate PTH/PTHrP system through the isolation, phylogenetic analysis and functional characterization of the chicken receptors.

Results: Two PTHRs were isolated in chicken and sequence comparison and phylogenetic analysis indicate that the chicken receptors correspond to PTH1R and PTH3R, which emerged prior to the teleost/tetrapod divergence since they are present in cartilaginous fish. The vertebrate PTH2R receptor and its ligand TIP39 have been lost from bird genomes. Chicken PTH1R and PTH3R have a divergent and widespread tissue expression and are also evident in very early embryonic stages of development. Receptor stimulation studies using HEK293 cells stably expressing the chicken PTH1R and PTH3R and monitoring CAMP production revealed they are activated by chicken 1-34 N-terminal PTH-family peptides in a dose dependent manner. PTH-L and PTHrP were the most effective peptides in activating PTH1R ( $E C_{50}=7.7 \mathrm{nM}$ and $\mathrm{EC}_{50}=22.7 \mathrm{nM}$, respectively). In contrast, PTH-L (100 nM) produced a small cAMP accumulation on activation of PTH3R but PTHrP and PTH ( $\mathrm{EC}_{50}=2.5 \mathrm{nM}$ and $\mathrm{EC}_{50}=22.1 \mathrm{nM}$, respectively) readily activated the receptor. PTHrP also stimulated intracellular $\mathrm{Ca}^{2+}$ accumulation on activation of PTH1R but not PTH3R.

Conclusion: Two PTHR homologues of the vertebrate PTH1R and PTH3R were isolated and functionally characterized in chicken. Their distinct pattern of expression during embryo development and in adult tissues, together with their ligand preference, suggests that they have acquired specific functions, which have contributed to their maintenance in the genome. PTH2R and its activating ligand, TIP39, are absent from bird genomes.

Nonetheless identification of putative PTH2R and TIP39 in the genome of an ancient agnathan, lamprey, suggests the PTH/PTHrP ligand and receptor family was already present in an early basal paraphyletic group of vertebrates and during the vertebrate radiation diverged via gene/genome duplication and deletion events. Knowledge of the role PTH/PTHrP system in early vertebrates will help to establish evolution of function.
\end{abstract}

\footnotetext{
* Correspondence: jccardo@ualg.pt

†Equal contributors

Centre of Marine Sciences, Comparative Molecular Endocrinology,

Universidade do Algarve, Campus de Gambelas, 8005-139 Faro, Portugal
} 


\section{Background}

The parathyroid hormone (PTH)-family consists of a group of structurally related factors that regulate calcium and bone homeostasis and a multitude of developmental processes (i.e. heart, mammary gland and immune system), which are mediated by calcium $[1,2]$. PTH, PTH-related protein (PTHrP) and the tuberoinfundibular peptide 39 (TIP39 a.k.a. PTH2) are members of the PTH-family in placental mammals. They are encoded by separate genes and in the protein share a conserved $\mathrm{N}$-terminal amino acid sequence, which is involved in receptor binding and activation [3-5]. In nonmammalian tetrapods and fish, an additional family member designated PTH-L exists [2,6]. The specific whole genome duplication that occurred in teleost fish means they possess duplicated gene homologues of the mammalian forms of PTH (PTH1/PTH2) and PTHrP (PTHrPA/PTHrPB) [6-8]. Peptides of this family are proposed to have emerged early during the vertebrate radiation as suggested by the recent characterization of the PTH/PTHrP family members in the cartilaginous fish the elephant shark (Callorhinchus milii) [9]. The number of receptors (PTHRs) identified for PTH family ligands varies from two in mammals, designated PTH1R and PTH2R, to three in teleost fish, which do not appear to have the full complement of duplicated PTHRs but instead contain mammalian orthologues and a third receptor designated PTH3R [10]. Recently, putative PTHR were predicted also in the tunicate Ciona intestinalis and in the mollusc Antarctic clam Laternula elliptica, suggesting that the evolution of PTHRs may have predated the vertebrate radiation $[11,12]$.

$\mathrm{PTH} / \mathrm{PTHrP}$ receptors are members of the family $2 \mathrm{~B} 1$ G-protein coupled receptors (GPCRs), a large group of seven transmembrane peptide and neuroendocrine receptors characterised by the presence of a large $\mathrm{N}$-terminal ectodomain ( $\mathrm{N}$-ted) involved in ligand interaction and by a C-terminal domain that is responsible for the activation of the intracellular signalling cascade [11,13-15]. At the N-ted, six conserved cysteine residues and $\mathrm{N}$-glycosylation sites are responsible for the formation of the ligand-binding pocket. Receptor activation triggers different intracellular signalling pathways, including the activation of protein kinases A (PKA) and accumulation of cAMP $[14,16,17]$ and phospholipase C leading to protein kinase $\mathrm{C}$ (PKC) and intracellular $\mathrm{Ca}^{2+}$ release $[16,18]$. Moreover, studies using in vitro cell assays and monitoring activation of intracellular signalling pathways established that receptor preference for the mammalian and teleost ligands are different. Human and zebrafish PTH1R are preferentially activated by both PTH and PTHrP. Zebrafish PTH2R binds exclusively to TIP39 while the human PTH2R is also activated by PTH [19]. PTH3R is preferentially activated by PTHrP, including fish PTHrPA [20-22]. Receptor preference for PTHrP1B and PTH-L remains to be determined.

Homologues of the mammalian PTH and PTHrP and the teleost PTH-L genes and transcripts were identified in chicken and Xenopus, and preliminary functional studies indicated that the $\mathrm{N}$-terminal peptides are able to stimulate calcium transport [2]. As with the human gene, chicken PTHrP produces several distinct transcript isoforms, and has a widespread tissue distribution. Furthermore, PTH was highly expressed in the chicken parathyroid gland and was the most potent peptide promoting calcium transport across the chorionallantois membrane (CAM) [2]. Despite the current lack of knowledge about the function of the PTH/PTHR systems in chicken, putative PTHR activated by PTHrP were reported in chicken bone and kidney [23-25]. Studies describing the action of PTH and PTHrP on chicken tibial growth plate chondrocytes (GPCs) suggest that they activate identical intracellular signalling pathways to those described for the mammalian and teleost homologues $[16,26]$. Homologues of PTH1R and PTH3R are predicted to exist in the chicken genome whereas PTH2R and its specific peptide ligand TIP39 seem to be absent $[27,28]$. Moreover, based upon in silico analysis it has been hypothesised that chicken PTH1R may be a pseudogene [27].

The aim of the present study is to contribute for the understanding of the evolution and function of the $\mathrm{PTH} / \mathrm{PTHrP}$ system in vertebrates by the isolation and characterisation of the $\mathrm{PTH} / \mathrm{PTHrP}$ receptors in chicken. To this end, PTHR sequences were identified in silico in the chicken genome and expressed sequence tags (EST) deposited in public databases and the fulllength receptors cloned. Gene expression in chicken adult and during embryonic development stages were characterised and the relative potency of the $\mathrm{N}$-terminal (1-34) region of chicken PTH and PTHrP in stimulating receptor activation determined by quantification of intracellular cAMP production and $\mathrm{Ca}^{2+}$ accumulation. The origin and evolution of the PTH/PTHrP systems in the vertebrate radiation was revisited by comparison of chicken ligands and receptors with homologues in other metazoan genomes.

\section{Results}

\section{The chicken PTH/PTHrP receptors}

In the chicken genome putative PTH1R (ENSGALG 00000005476) and PTH3R (ENSGALG00000019797) were identified. The predicted mature transcripts of chicken PTH1R and PTH3R are 1614 bp and 1626 bp in length that correspond to deduced proteins of 538 and 542 amino acids, respectively, both containing putative signal peptide sequences and sharing $54 \%$ overall amino acid 
sequence identity. The chicken PTH1R mRNA (Accession number FR746109, Additional file 1) was confirmed by RT-PCR on cDNA from whole chicken embryos at stage $26 \mathrm{HH}$ and from $3 \mathrm{ESTs}$ found in database from stage 20-21HH whole chick embryos (BU219643), from stage 36HH limbs (BU401969) and from growth plate chondrocytes (BU419888). The chicken PTH3R (Accession number FR746110, Additional file 2) was also confirmed by RT-PCR on the same cDNA sample but no EST was found. Despite thorough database searches and attempts to amplify a chicken PTH2R receptor using degenerate primers on genomic DNA and cDNA a homologue was not identified.

Multiple sequence alignment of the deduced amino acid sequence of chicken PTHRs with mammalian and teleost homologues (Figure 1) revealed the chicken PTH1R shares at least $76 \%$ similarity to other vertebrate PTH1Rs and that the chicken PTH3R is $71 \%$ similar with the zebrafish PTH3R. The seven transmembrane domains (TM) and the six cysteine residues at the N-ted are fully conserved across vertebrates (Figure 1) as are four putative $\mathrm{N}$-glycosylation sites (Nx[TS]) in PTH1R two of which are also found in PTH3R. The chicken PTHR N-ted also contains the residues $\mathrm{L}^{13}, \mathrm{~T}^{33}, \mathrm{Q}^{37}$, $\mathrm{F}^{184}, \mathrm{R}^{186}, \mathrm{~L}^{187}$ and $\mathrm{I}^{190}$ previously identified to be involved in the interaction of mammalian PTH1R with PTH(1-34) and PTHrP(1-34) [13,29]. The only amino acid residues in $\mathrm{N}$-ted that are not conserved are $\mathrm{L}^{13}$ which is replaced by $\mathrm{I}^{13}$ in PTH1R and $\mathrm{I}^{190}$ which substituted by $\mathrm{M}^{190}$ in PTH3R (Figure 1). The residues $\mathrm{D}^{113}$, $\mathrm{W}^{118}, \mathrm{P}^{132}$ and $\mathrm{W}^{154}$ which are involved in the structural conformation of the ligand-binding pocket of family $2 \mathrm{~B} 1$ GPCRs $[11,30]$ are also conserved in the chicken receptor sequences.

\section{PTH/PTHrP receptor homologues in vertebrate and invertebrate genomes}

To place in context the evolution of chicken PTHRs, potential PTH/PTHrP homologues from other vertebrate and invertebrate genomes were retrieved from public databases (Table 1). In Xenopus, and lizard genomes, partial sequences for putative PTH1R, PTH2R and PTH3R were identified. In the bird genomes - zebra finch, turkey and duck - only homologues of the chicken PTH1R (ENSTGUG00000000188, ENSMGAG00000002767 and ENSAPLG00000005598, respectively) and PTH3R (ENS TGUG00000001924, ENSMGAG00000001866 and ENS APLG00000010124, respectively) genes were retrieved. The deduced mature peptide sequence of the bird PTHRs identified are highly conserved with the chicken homologues and share at least $75 \%$ and $83 \%$ with PTH1R and PTH3R, respectively. In the recently available genome of the cartilaginous fish, elephant shark, three potential receptors (homologues of the vertebrate PTH1R,
PTH2R and PTH3R) were identified and in lamprey two PTH/PTHrP receptors seem to be present (Table 1). Among the invertebrate chordates two potential PTH/ PTHrP receptors were identified in the Ciona genome (Ciona_a, ENSCING00000002669 on scaffold_67 and Ciona_b, ENSCING00000006282 in scaffold_162) and in the amphioxus Branchiostoma floridae genome (XM_002599399) a PTH/PTHrP receptor gene also appears to be present. Amino acid sequence similarity of the predicted Ciona_a and Ciona_b receptors is 46\% and 49\%, respectively, with the chicken PTH1R and 45\% and 47\% from amphioxus with the paralogue PTH3R. The deduced PTH receptor from amphioxus shares $49 \%$ and $47 \%$ sequence similarity with the chicken PTH1R and PTH3R, respectively.

\section{PTH/PTHrP receptor gene structure and short-range gene linkage}

The chicken PTH1R and PTH3R share a complex gene organisation and are composed of 13 exons and are identical with the predicted gene structures of their homologues in Xenopus and zebrafish (Additional file 1 and Additional file 2). This contrasts to human PTH1R that contains 15 exons within the mature receptor region. For both chicken PTH1R and PTH3R, the signal peptide region is encoded within the $1^{\text {st }}$ exon and the TM regions are distributed between the $5^{\text {th }}$ and $13^{\text {th }}$ exon.

Gene synteny was maintained for both PTH1R and PTH3R and linked genes were found in chicken, zebrafish, Xenopus and human (Figure 2). The PTH1R gene maps to chicken chromosome 2, to human chromosome 3, to Xenopus scaffold 479, and to zebrafish chromosome 2 and the gene TMIE (transmembrane inner ear-like) was found to be conserved within the compared homologue genome regions. The chicken PTH3R gene maps to chromosome 27 and is homologous to Xenopus scaffold_155 and zebrafish chromosome 12. The gene TACO1 (translational activator of mitochondrially encoded cytochrome c oxidase I) was found to be common in the teleost and tetrapod genome regions analysed.

Despite the apparent absence of a putative PTH2R gene, chicken homologue genes that are conserved in the vertebrate PTH2R gene environment were also found in a conserved cluster in the chicken genome (Figure 2). The genes IDH1 (isocitrate dehydrogenase) and PIP5K3 (1-phosphatidylinositol-4-phosphate 5-kinase) found in close proximity to the zebrafish, Xenopus and human PTH2R were identified on chicken chromosome 7. Similarly, the human genome homologues of the conserved vertebrate PTH3R gene environment were also identified on chromosome 17. 


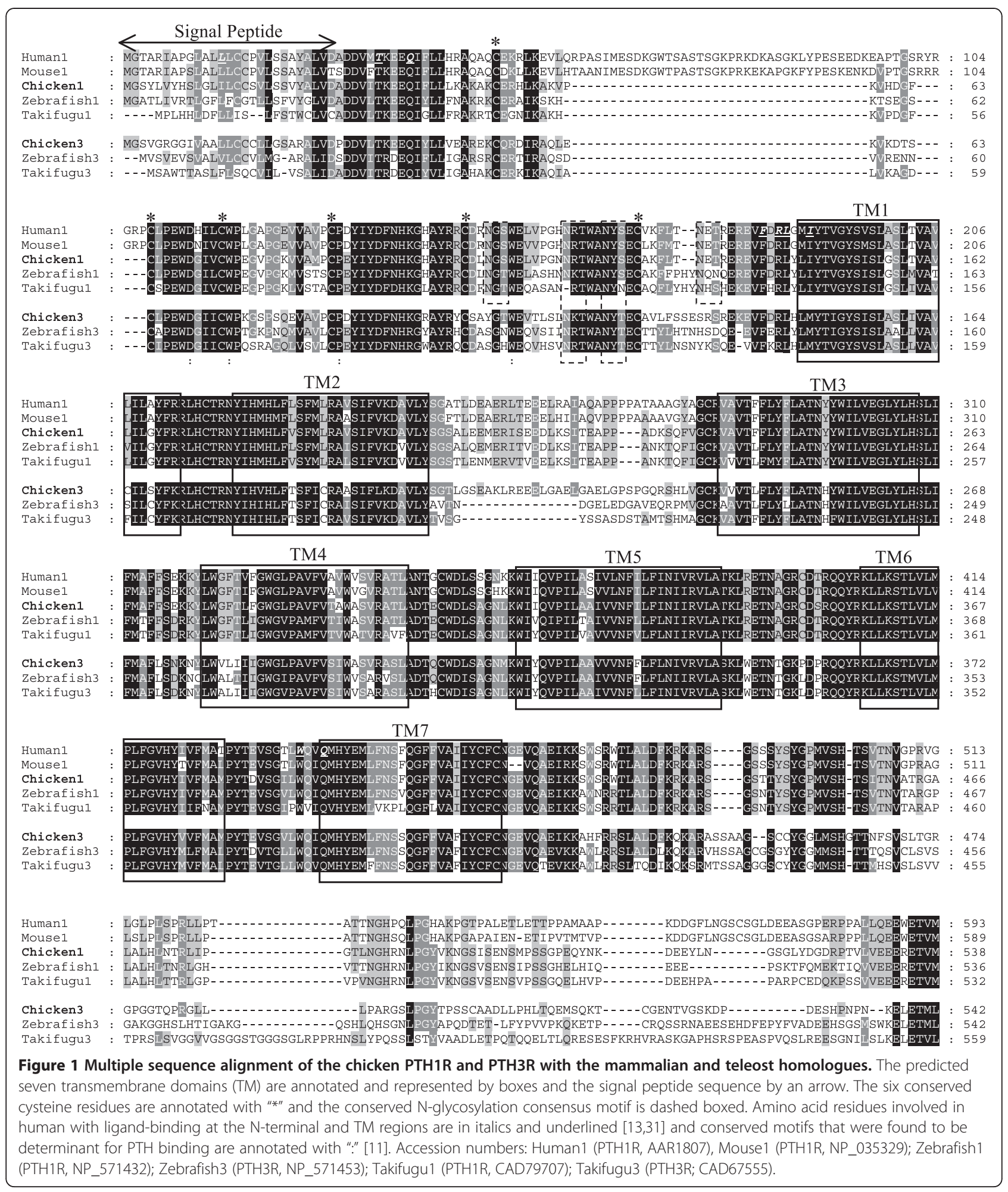

Comparative analysis with the homologue genome regions in the Ciona genome indicates that Ciona PTHR (Ciona_a) located in scaffold_67 shares gene environment conservation with the vertebrate PTH1R. Putative homologues of the vertebrate $A L S 2 C L$ and JMJD4 are also predicted in the Ciona homologue genome region, which contrasts with Ciona_b gene environment in scaffold_162, where there was no gene synteny. In the amphioxus 
Table 1 Accession numbers of predicted vertebrate PTHR genes

\begin{tabular}{|c|c|c|c|c|}
\hline Common name & Scientific name & PTH1R & PTH2R & PTH3R \\
\hline Human & Homo sapiens & ENSG00000160801 & ENSG00000144407 & Not identified \\
\hline Opossum & Monodelphis domestica & ENSMODG00000013964 & ENSMODG00000015872 & Not identified \\
\hline Platypus & Ornithorhynchus anatinus & ENSOANG00000020450 & ENSOANG00000008008 & Not identified \\
\hline Chicken & Gallus gallus & ENSGALG00000005476 & Not identified & ENSGALG00000019797 \\
\hline Zebra finch & Taeniopygia guttata & ENSTGUG00000000188 & Not identified & ENSTGUG00000001924 \\
\hline Turkey & Meleagris gallopavo & ENSMGAG00000002767 & Not identified & ENSMGAG00000001866 \\
\hline Duck & Anas platyrhynchos & ENSAPLG00000005598 & Not identified & ENSAPLG00000010124 \\
\hline Lizard & Anolis carolinensis & ENSACAG00000004743 & ENSACAG00000011092 & ENSACAG00000003901 \\
\hline African clawed frog & Xenopus tropicalis & ENSXETG000000003683 & ENSXETG00000008019 & ENSXETG000000003243 \\
\hline Zebrafish & Danio rerio & ENSDARG00000020957 & ENSDARG00000006678 & ENSDARG00000018418 \\
\hline Takifugu & Takifugu rubripes & ENSTRUG00000013866 & ENSTRUG00000006000 & ENSTRUG00000002272 \\
\hline Elephant shark & Callorhincus milii & $\begin{array}{l}\text { AAVX01252370.1 } \\
\text { AAVX01556909.1 } \\
\text { AAVX01305998.1 }\end{array}$ & $\begin{array}{l}\text { AAVX01159975.1 } \\
\text { AAVX01100591.1 }\end{array}$ & $\begin{array}{l}\text { AAVX01012445.1 } \\
\text { AAVX01295680.1 }\end{array}$ \\
\hline Lamprey & Petromyzon marinus & GENSCAN00000088236 & GENSCAN00000077871 & Not identified \\
\hline
\end{tabular}

Species names of published genomes and database accession numbers of identified PTH1R, PTH2R and PTH3R.

genome a homologue of the vertebrate TMIE is predicted in close proximity with the putative PTHR locus (scaffold_98).

\section{Phylogenetic analysis of PTH/PTHrP receptors}

Phylogenetic analysis of the chicken PTH1R and PTH3R with the retrieved vertebrate and invertebrate homologues is shown in Figure 3A. The consensus tree obtained suggests that the PTH/PTHrP receptors emerged early during the deuterostome radiation. The vertebrate PTHR members shared a common ancestor gene with Ciona and amphioxus and have evolved via gene or genome duplications. Two major clades are present one containing the vertebrate PTH2R and the other clusters PTH1R and PTH3R. This suggests that after the initial gene duplication they have been under different evolutionary pressure and that the vertebrate PTH1R and PTH3R are the result of a recent duplication event. The chicken and other avian PTH/PTHrP receptors cluster within the PTH1R/PTH3R group, confirming their homology (Figure 3A). The three Xenopus and lizard PTH/ PTHrP receptors group with the teleost homologues. In Ciona the existence of two PTHRs appears to be the result of a specific duplication event.

\section{TIP39 genes in vertebrates}

The absence of PTH2R in chicken raises questions about the presence in the genome of its putative ligand TIP39. Searches performed on the chicken genome and EST databases failed to identify the homologue of human and teleost TIP39. However, a putative TIP39 gene is predicted in the Xenopus (ENSXETG00000027477) genome and also in non-annotated regions of the lizard (Scaffold
GL343355), Platypus (SuperContig Contig8806) and Opossum (chromosome 4) genomes. In addition, in lamprey (GL477315) and elephant shark (AAVX01305587.1) a putative TIP39 gene also seems to be present. In elephant shark, four PTH-family genes were identified clustering with PTH, PTHrP, TIP39 and PTH-L (Figure 3B). No potential TIP39 gene was identified in the tunicate Ciona and amphioxus genomes, suggesting that this gene is specific to vertebrates. Phylogenetic analysis of the deduced TIP39 mature peptides with the PTH/ PTHrP members confirmed that the TIP39 clade is basal and shared common origin (Figure $3 \mathrm{~B}$ ). Characterization of the vertebrate TIP39 gene environment revealed that gene order and gene synteny is only conserved in Xenopus and human and no conserved genes were found in teleost and lamprey (Additional file 3).

\section{Tissue gene expression}

Tissue expression of the chicken PTHRs transcripts was characterised in several adult tissues and during embryo development. The chicken PTH1R was detected in all adult tissues and embryo stages analysed (Figure 4). During embryo development PTH3R was expressed from stage $4 \mathrm{HH}$ (19 hours of incubation) onwards, but was absent or down-regulated in the head of $31 \mathrm{HH}$ and $36 \mathrm{HH}$. The chicken PTH3R was also detected in most of the adult tissues despite its low level of expression, but highest transcript expression was found in intestine (hindgut), lung, liver and cartilage (Figure 4).

\section{Receptor activation of cAMP production}

The cAMP accumulation of a stable cell line expressing chicken PTH1R and PTH3R in the presence of chicken 
$\mathrm{PTH}(1-34)$, PTHrP(1-34) and PTH-L(1-34) is shown in Figure 5. All chicken peptides were able to activate the two receptors in a dose-dependent manner with different half maximal concentrations $\left(\mathrm{EC}_{50}\right)$. Furthermore, the accumulation of cAMP in cells transfected with PTH3R was almost one order of magnitude larger compared to those with PTH1R. PTHrP produced the highest stimulation of PTH1R $(\mathrm{p}<0.05)$ and together with PTH-L was the most efficient peptide (Table 2). Stimulation of PTH3R was highest for PTHrP and PTH, while PTH-L (100nM) only produced a small cAMP accumulation above basal levels and was approximately 13 times lower than PTH and PTHrP $(\mathrm{p}<0.05)$. The $\mathrm{EC}_{50}$ followed the same pattern with PTH-L in the $\mu \mathrm{M}$ range
(Table 2). Human PTH was also able to stimulate chicken PTH1R $\left(21.4 \pm 10 \mathrm{pmol} /\right.$ well at $\left.10^{-7} \mathrm{M}\right)$ (Additional file 4). Human TIP39 failed to induce accumulation of cAMP with PTH1R and only negligible cAMP production was obtained for PTH3R (Additional file 4).

\section{Receptor activation of intracellular $\mathrm{Ca}^{2+}$}

A peptide screen using $1 \mu \mathrm{M}$ and $100 \mathrm{nM}$ of each PTH and PTHrP peptide revealed that irrespective of the peptide PTH3R activation did not cause release of intracellular $\mathrm{Ca}^{2+}\left(\mathrm{iCa}^{2+}\right)$. However, PTHrP efficiently stimulated $\mathrm{iCa}^{2+}$ accumulation with PTH1R with an $\mathrm{EC}_{50}$ of $2.6 \mathrm{nM}$ and PTH-L $(1 \mu \mathrm{M})$ caused only a slight stimulation and PTH had no effect (Figure 6). 


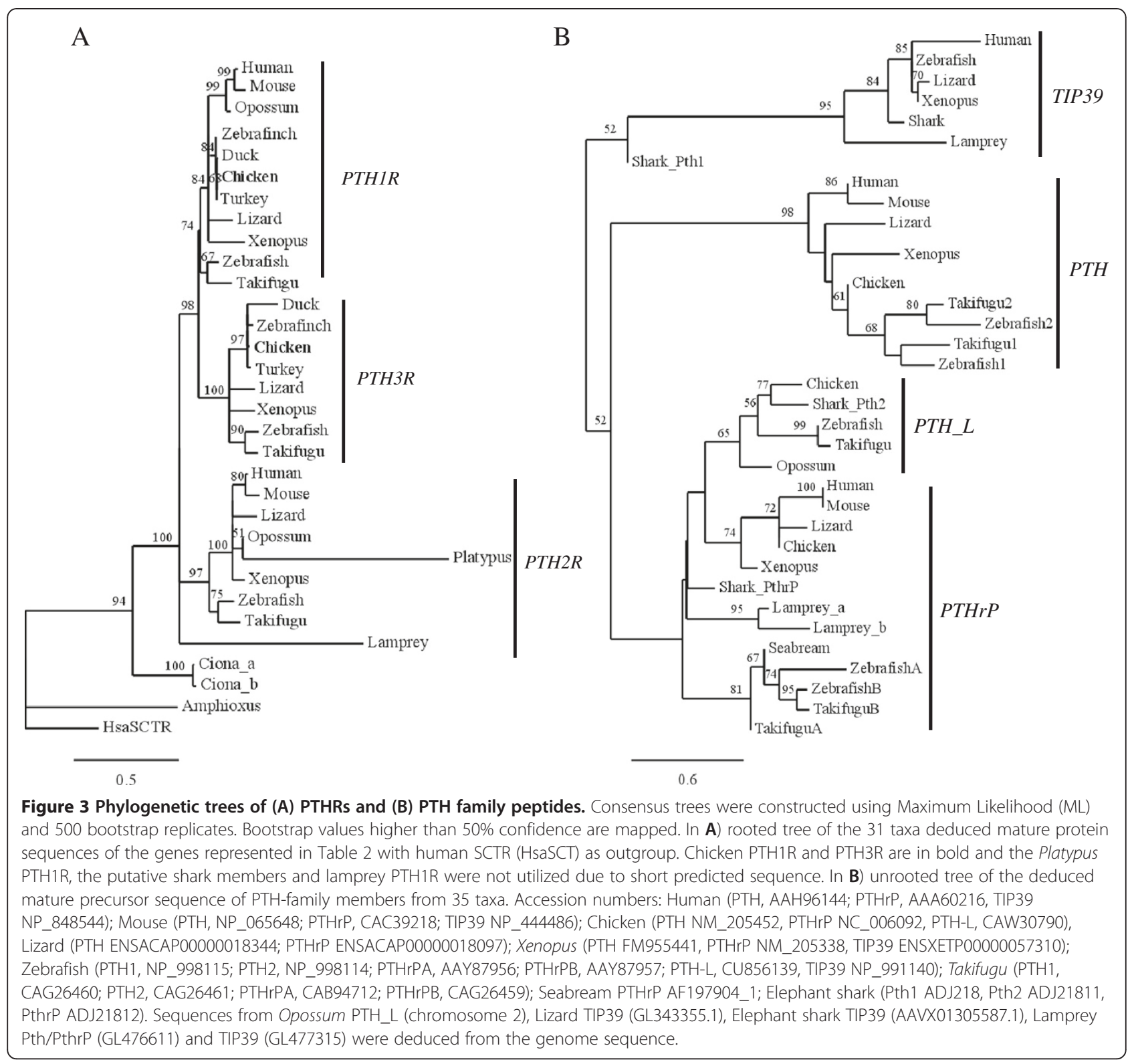

\section{Discussion}

Homologs of PTH1R and PTH3R, but not PTH2R, are present in the chicken genome, and are the result of a gene duplication, which occurred prior to the divergence of fish. The chicken PTHRs have a widespread tissue distribution and are activated by the N-terminal 1-34 fragment of PTH-family peptides. The presence in the two receptors of conserved amino acids important for ligand-binding in $\mathrm{N}$-ted and residues $\mathrm{W}^{437}$ and $\mathrm{Q}^{440}$ located within the third extracellular loop and TM7, respectively, suggests the function of the chicken receptors is similar to the human PTH1R [13,32]. The genomic structure of chicken PTH1R is similar to fish and amphibian while the human homologue gene contains two extra exons: exon 2, which corresponds to an extracellular loop exclusive of the mammalian receptor and exon 15 which is the result of intron gain within one of the exons encoding the C-terminus of the receptor [33].

PTH1R and PTH3R are expressed during chicken development and in many different adult tissues, including the classical calcium-target tissues such as kidney, intestine, bone and cartilage. In human, PTH1R is also expressed in kidney and in a variety of other tissues, and is activated by both PTH and PTHrP, and accounts for the autocrine/paracrine function of PTHrP [19,34,35]. In fish, PTH1R was mainly expressed in the scales, liver, gonad, skin, brain and pituitary $[1,36,37]$. The Xenopus lung epithelium produces PTHrP which regulates, through a receptor-mediated mechanism, mesodermal 

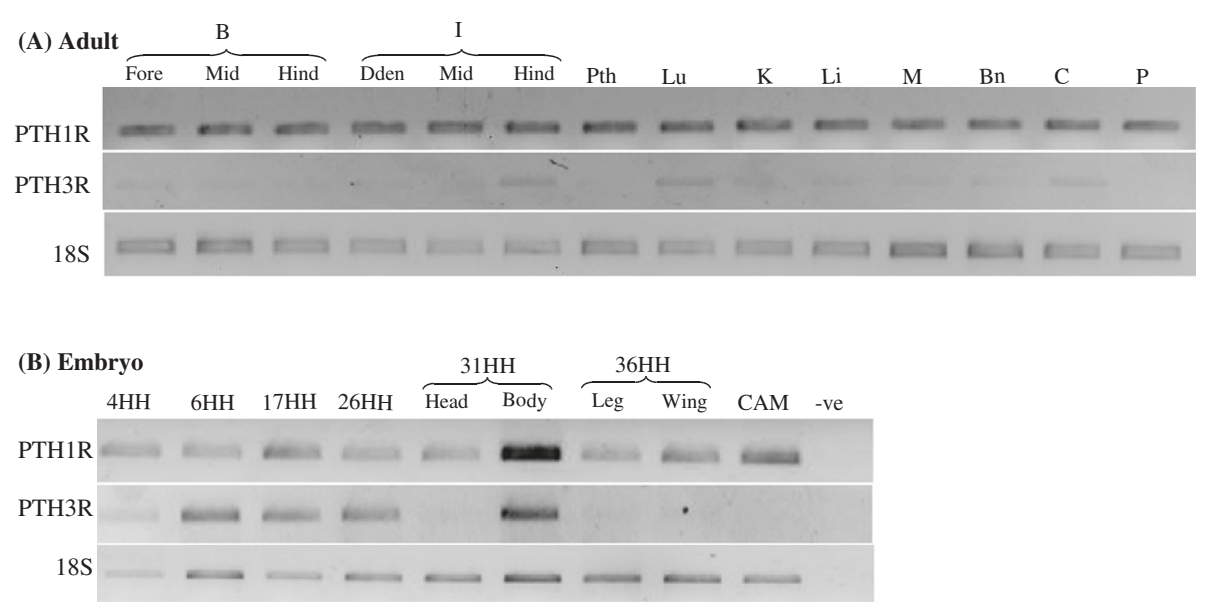

Figure 4 Tissue expression of the chicken PTH1R and PTH3R in adult (A) and embryonic stages (B). The RT-PCR reactions for A) and B) were carried out simultaneously using transcript specific primers and ribosomal subunit $18 \mathrm{~S}$ as reference. In B the chicken the embryos were at different Hamburger and Hamilton stages, $(\mathrm{HH})$ and CAM was obtained from stage 44HH. B-brain (forebrain, midbrain, hindbrain); I-intestine; Dden-duodenum; Mid-midgut; Hind-hindgut; Pth-parathyroid; Lu-lung; K-kidney; Li-liver; M-muscle; Bn-bone; C-cartilage; P-pituitary; CAM- chorionallantois membrane; -ve-negative.

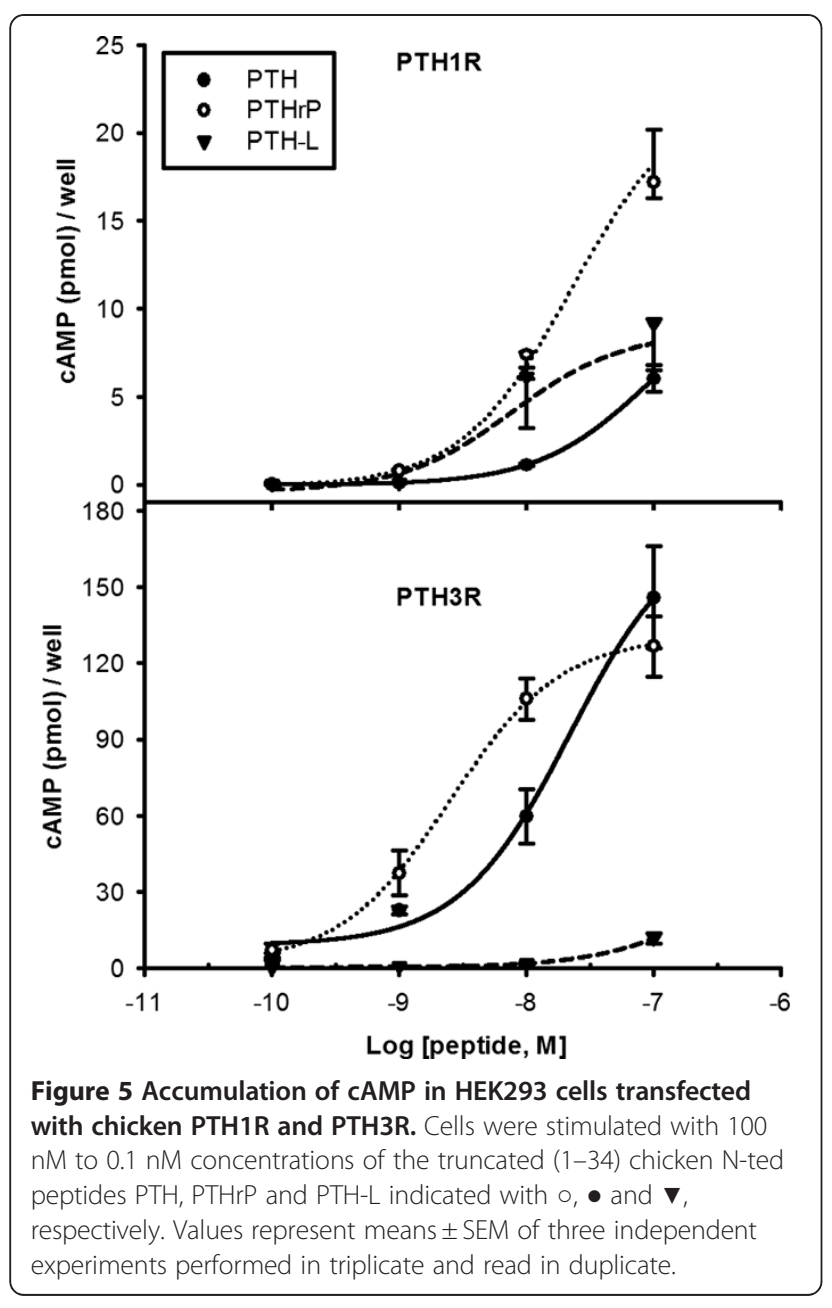

leptin necessary for lung development [38]. The receptor responsible is likely to be PTH1R, which in Xenopus laevis is expressed in lung, brain, skin, kidney and bone [39]. There is much less information available about the characteristics of PTH3R and in chicken it is most highly expressed in the hindgut, lung and cartilage. In fish, PTH3R has been identified in the interrenal tissue where it may regulate cortisol secretion [40] and from intestine where it signals primarily via the adenylate cyclase/protein kinase A (AC/PKA) signalling pathway possibly mediating calcium uptake [41].

PTHRs are expressed in developing bone/cartilage structures in the embryo and have a key role during development. In mammals, PTH1R in association with Indian hedgehog $(\mathrm{IHH})$ signalling regulate endochondral bone ossification and skeletal development [42-44]. Previous studies with chicken embryos reveal that, prior to the appearance of skeletal tissue, PTHrP and PTH1R are co-expressed by cells of the ectoderm, skeletal muscle, peripheral nerve and mesenchyme [25]. Hyaline cartilage in chicken first observed at $\mathrm{HH} 27$, co-express PTHrP and PTH1R in chondroblasts but by day 37 the chondrocytes do not express the receptor which is present in the perichondrium as well as in preosteoblasts, osteoblasts and osteocytes [25]. The calcium necessary for chicken embryo development is likely to be regulated by the egg CAM [2] and probably involves the activation of chicken PTH1R, which is the only PTHR amplified from this tissue. In the current study, the low expression of PTH3R in head, legs and limbs but high expression in the body of the developing embryo suggests this receptor may be more important in the development of non-skeletal tissues. 
Table 2 Potency and efficacy of the chicken 1-34 N-terminal PTH peptides on PTH1R and PTH3R cAMP production

\begin{tabular}{|c|c|c|c|c|c|c|}
\hline & \multicolumn{3}{|c|}{ PTH1R } & \multicolumn{3}{|c|}{ PTH3R } \\
\hline & $\mathrm{EC}_{50}(\mathrm{nM})$ & 95\% Confidence Intervals (nM) & $\mathrm{E}_{\max }(\mathrm{pmol} / \mathrm{well})$ & $\mathrm{EC}_{50}(\mathrm{nM})$ & 95\% Confidence Intervals (nM) & $E_{\max }(p m o l / w e l l)$ \\
\hline $\mathrm{PTH}$ & 92.1 & 11.4 to 743.5 & $6.03 \pm 0.78$ & 22.1 & 7.1 to 68.4 & $144.7 \pm 20.02$ \\
\hline PTHrP & 22.7 & 10.7 to 48.4 & $17.21 \pm 1.84 *$ & 2.5 & 1 to 6.1 & $119.9 \pm 11.76$ \\
\hline PTH-L & 7.7 & 1.5 to 39.9 & $9.13 \pm 1.44$ & 306.9 & 27.7 to $3.4 \mathrm{e}^{+10}$ & $12.6 \pm 2.13 *$ \\
\hline
\end{tabular}

Peptides tested, cAMP production, 95\% confidence intervals and maximal cAMP production $\mathrm{E}_{\max }$ (mean \pm SEM). Each result is an average of 3 experiments carried out in triplicate. ${ }^{*}$ indicates statistical significance compared to other peptides $(p<0.05)$.

Chicken PTHRs are activated by PTH-family peptides in a dose-dependent manner. $\operatorname{PTHrP}(1-34)$ was the most potent peptide overall and stimulated cAMP accumulation through PTH1R and PTH3R and had overlapping potency with $\mathrm{PTH}(1-34)$ for the latter receptor. Mammalian PTH1R is activated by both PTH and PTHrP which have similar potency and stimulate both cAMP and $\mathrm{iCa}^{2+}$ production [45]. Zebrafish PTH1R is activated similarly by the N-terminal peptides of fugu PTHrPA, human PTHrP and PTH and zebrafish PTH1 but not zebrafish PTH2 while zebrafish PTH3R has preference for fugu PTHrPA, human PTHrP and zebrafish PTH1 and PTH2 but not for human PTH $[8,10]$. Human PTH activated chicken PTH1R and stimulated cAMP production with an apparently similar potency to chicken PTHrP. Interestingly, chicken PTH-L had a low capacity to activate any of the receptors, which is consistent with its lower potency in stimulating calcium transport across the CAM [2]. Whether PTH-L binds to another as yet unidentified receptor(s) or is a less active PTH-family member in chicken remains to be established.

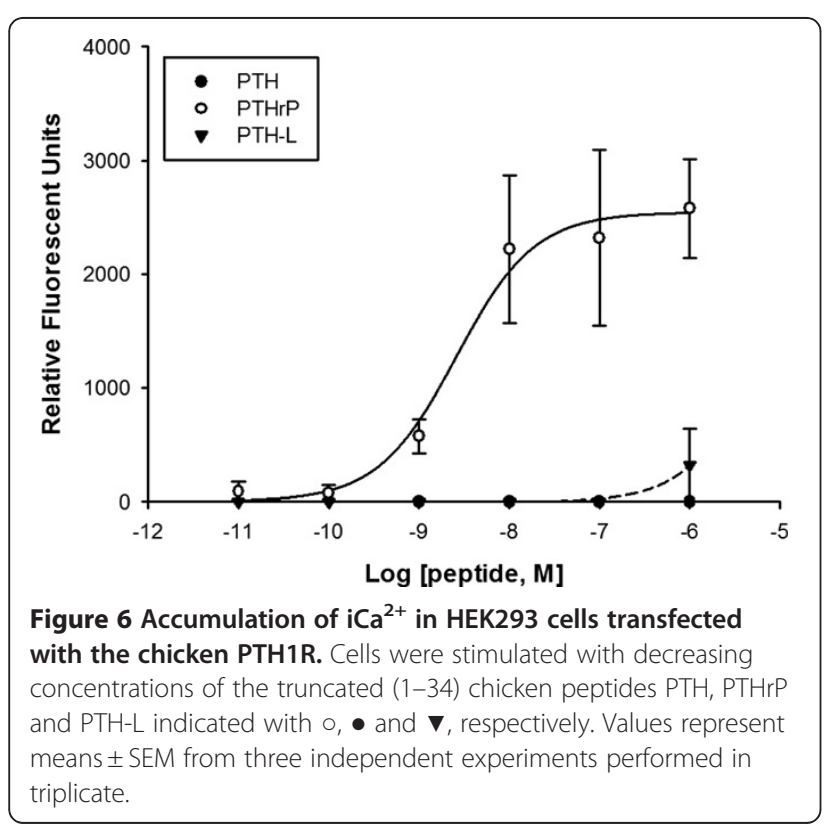

Of the two chicken receptors, PTH3R accumulated one order of magnitude more cAMP than PTH1R. This is to some extent surprising as HEK293 cells express PTH1R at a low level [46]. It may indicate that the two receptors use a different complement of signalling molecules (e.g., G-protein $\alpha$-subunits, adenylyl cyclases) or they may interact with receptor auxiliary proteins which remain to be characterised [46]. In contrast, only PTH1R stimulates accumulation of $\mathrm{iCa}^{2+}$. Similar observations were made for zebrafish PTH1R and PTH3R and activation with PTH/PTHrP peptides stimulated cAMP accumulation but only PTH1R, was capable of activating $\mathrm{IP} 3 / \mathrm{iCa}^{2+}$ signalling [10]. In sea bream scales, where only PTH1R is expressed, piscine PTHrPA(1-34) activated both the adenylyl cyclase/protein kinase A (AC/PKA) and phospholipase $\mathrm{C} /$ protein kinase $\mathrm{C}$ (PLC/PKC) signalling cascades [37]. Deletions of $\mathrm{N}$-terminal amino acids in piscine PTHrPA reduced cAMP accumulation, but had no effect on PLC/PKC signalling [37]. Moreover piscine PTHrP(1-34) was also found to stimulate cAMP accumulation in isolated sea bream enterocytes via PTH3R but no activation of the PLC/PKC pathway was detected [41]. The results of the present study indicate that chicken PTH1R and PTH3R are functionally different and this observation with the differing tissue expression supports the idea of differential cellular functions. It remains to be established if chicken PTHRs activate other intracellular signalling pathways such as the mitogen-activated protein kinase or interact with proteins such as RAMPs (receptor-activating-modifying proteins) or calmodulins known to modulate the activity of the mammalian receptor [reviewed by 19,47].

The functional importance of calcium from single cell organisms to metazoan has required the evolution of mechanisms for its regulation and the suggestion that the PTH family may be ancient. For example, it has been suggested that TIP39 may be present in yeast [48] but this seems to be the consequence of coincident gene names rather than authentic sequence similarity [49]. Immunohistochemical studies with heterologous antisera suggest that PTH exists in invertebrates such as snail, cockroach and amphioxus [50]. Studies in snail also suggest a potential neuropeptide role for the invertebrate $\mathrm{PTH} / \mathrm{PTHR}$ system, as mammalian PTH was found to 
stimulate calcium influx in neurons and induce depolarization and modulation of neural transmission through the inositol-triphosphate second messenger system [50-52]. However, Western blot failed to detect PTH immunoreactive material in neural extracts of prawn, squid, cuttlefish, starfish, dogfish, skate or hagfish [52]. Moreover, mining of invertebrate molecular databases failed to identify putative $\mathrm{PTH}$-family homologues and their existence remains to be conclusively demonstrated. In contrast, in silico analysis identified potential homologues of the vertebrate PTHRs in early deuterostome and protostome genomes [11,12].

Both PTH/PTHrP and their receptors seem to be present in lamprey and cartilaginous fishes (Figure 7). In the lamprey, the genome region GL476611 contained two potential PTH/PTHrP-like genes that shared similarity with the vertebrate homologues and were in linkage with the BTBD10 gene, which is present in the vertebrate PTH gene environment [2] (Additional file 3). A putative TIP39 gene is also present in the lamprey. In the elephant shark besides the previously reported PTH (Pth1) and PthrP homologues [9] putative TIP39 (Pth2) and PTH-L (Pth2 of Liu et al. [9]) genes were identified. This suggests that the gene/genome duplication event that generated the vertebrate PTH/PTHrP family occurred prior to or early in the origin of vertebrates (Figure 7 ). However, isolation of full-length lamprey transcripts is still required to permit full characterization of the PTH/ PTHrP family in early vertebrates.

Two putative PTHR-like receptor genes (PTH1R-like and PTH2R-like) and three homologues of the vertebrate PTH1R, PTH2R and PTH3R genes are predicted in the lamprey and elephant shark genomes, respectively, suggesting that the evolution of both peptides and their receptors occurred in the same time-frame. Nevertheless, the identification of putative PTHRs in invertebrate genomes and the apparent absence of homologues of their vertebrate PTH/PTHrP ligands suggest that PTHRs which occur in the invertebrate lineage pre-dated the emergence of their vertebrate ligands (Figure 7), an evolutionary pattern that is also common to other $2 \mathrm{~B} 1$ GPCR family members [53].

The duplication of PTH-family members and their specific receptors has occurred early in the vertebrate radiation. The emergence of seems to have accompanied the proposed two rounds of gene/genome duplication events that occurred at the basis of vertebrates [54-57]. The putative PTH1R/PTH3R gene precursor and

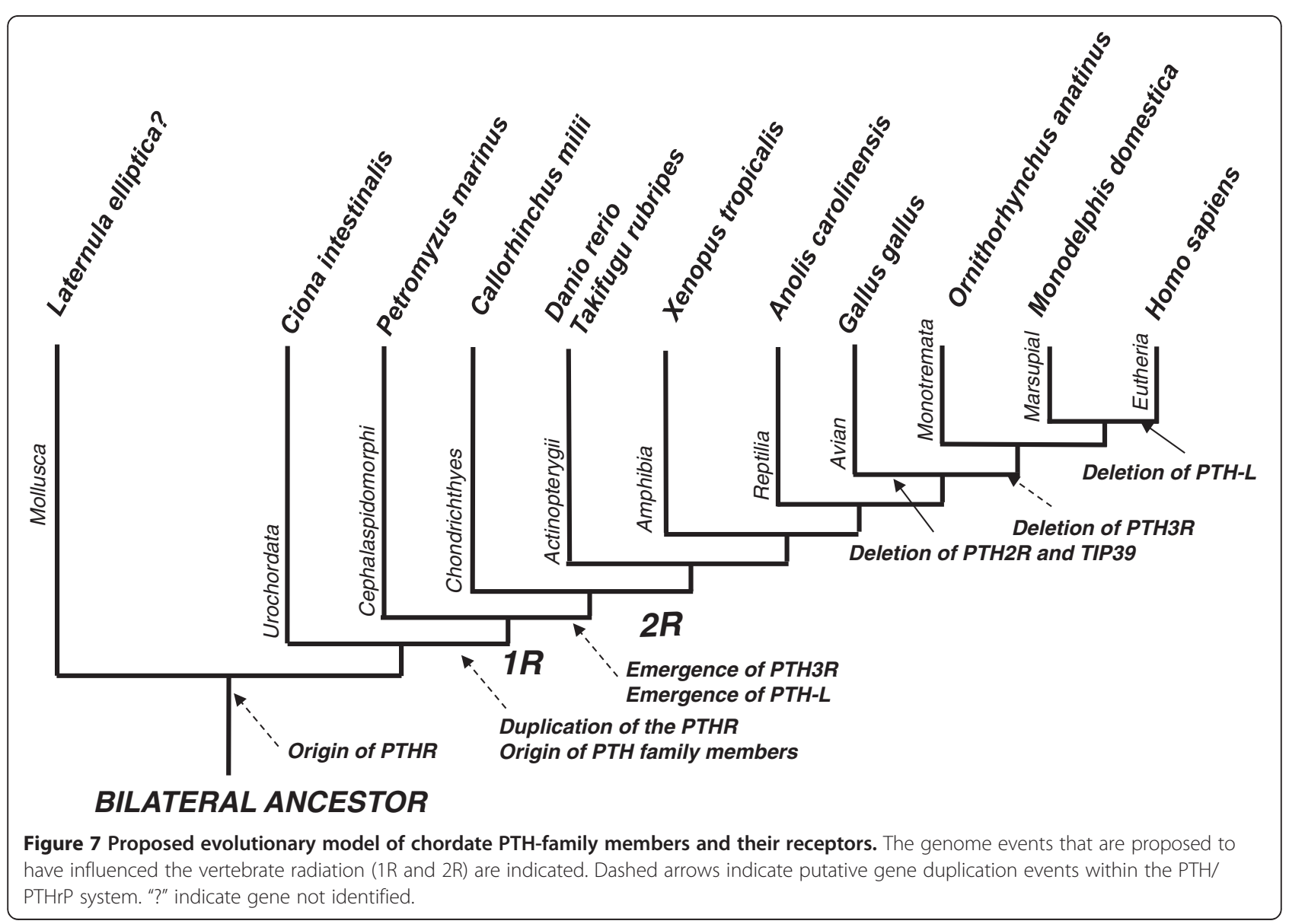


PTH2R gene are suggested to have emerged earlier, prior to or at the origin of vertebrates (1R), and PTH1R and PTH3R genes diverged subsequently prior to the Chondrichthyes (cartilaginous fish) radiation (2R). If a putative duplicate PTH4R gene existed it was eliminated from the genome.

The origin of PTH/PTHrP family members and TIP39 occurred early in vertebrate evolution and probably before the divergence of lamprey since a putative PTH-L was found in cartilaginous fish. Later in evolution gene deletions occurred as revealed by the absence of PTH2R and its ligand TIP39 in birds, proposed to result from a chromosome segment deletion in the bird genome [28]. Similarly, PTH3R and PTH-L are absent from placental mammal genomes (human and mouse). Thus, while putative ligands are only discernible in early vertebrates, the receptors seem to have an earlier origin.

\section{Conclusions}

Two PTHR homologues of the vertebrate PTH1R and PTH3R were isolated and functionally characterized in chicken. Their distinct pattern of expression during embryo development and in adult tissues, together with their distinct activation response to the potential ligands, suggests that they have acquired specific functions, which contributed to their maintenance in the bird genome. The chicken genome lacked a homologue of the vertebrate PTH2R and of its specific ligand TIP39, a feature shared by all avian genomes analysed. PTHR and PTH-family members have evolved via gene/genome duplications and deletion events and the identification of putative homologues in the primitive lamprey genome suggests that they emerged early and co-evolved during the vertebrate radiation. Knowledge of the role PTH/ PTHrP system in early vertebrates will help to establish their functional evolution.

\section{Methods}

\section{Animals and tissue collection}

All procedures with animals were performed in accordance with Portuguese legislation under a "Group-1" licence from the Direcção-Geral de Veterinária, Ministério da Agricultura, do Desenvolvimento Rural e das Pescas, Portugal. Tissues for gene expression analysis were obtained from adult white leghorn chickens (Gallus gallus), anesthetized with diethyl ether (Merck, Spain) before sacrifice by decapitation. Fertile chicken eggs to produce embryos were obtained from Quinta da Freiria (Serpa, Portugal) and kept at $37.6^{\circ} \mathrm{C}$ under high humidity in an automatic incubator (Brinseca OCTAGON 40) with gentle rotation. Developmental stages [58] selected for analysis coincided with the presence of prominent calcified structures: $4 \mathrm{HH}$ (definitive primitive streak process); $6 \mathrm{HH}$ (head and neural folds); 17
$\mathrm{HH}$ (leg bud formation); $26 \mathrm{HH}$ (toes formation); $31 \mathrm{HH}$ (feather germs; emergence of the interdigital membrane) and $36 \mathrm{HH}$ (labial groove; uropygial gland). The chorionallantois membrane (CAM) from 44 $\mathrm{HH}$ which increases calcium transport in response to $\mathrm{PTH}$-family peptides [2] was also collected. Tissues were snap frozen in liquid nitrogen and stored at $-80^{\circ} \mathrm{C}$ until use.

\section{In silico database searches}

Genomes and EST databases were interrogated for PTH/ PTHrP receptor homologues using the human (PTH1R, AAR18076; PTH2R, AAH36811) and zebrafish (PTH1R, NP_571432; PTH2R, NP_571452; PTH3R, NP_571453) deduced protein sequences with tBLASTn and default settings [59]. The following databases were searched: 1) the Ensembl genome and pre_ensembl (http://www.ensembl. org) genome assemblies of chicken, opossum (Monodelphis domestica), platypus (Ornithorhynchus anatinus), zebra finch (Taeniopygia guttata), turkey (Meleagris gallopavo), duck (Anas platyrhynchos), toad (Xenopus tropicalis), lizard (Anolis carolinensis), sea lamprey (Petromyzon marinus), 2) the the elephant shark (Callorhinchus milii) genome assembly at http://esharkgenome.imcb.a-star.edu. sg, 3) the chicken EST database (dbEST) of the Biotechnology and Biological Sciences Research Council (http:// www.chick.manchester.ac.uk/), the dbEST subsets Aves (taxid:8782), lamprey (taxid:7745) and cartilaginous fishes (taxid:7777) of the National Center for Biotechnology Information (NCBI, http://www.ncbi.nlm.nih.gov/). Due to the short size of contigs of the shark genome assembly searches were carried out using the coding sequence of the human and zebrafish PTHRs transmembrane (TM) domains retrieved from PRINTs database (http://www. bioinf.manchester.ac.uk/dbbrowser/PRINTS/).

The presence of a putative TIP39 and PTH/PTHrP genes in early vertebrate genomes of the elephant shark, lamprey and early deuterostomes Ciona intestinalis and Branchiostoma floridae (JGI genome assembly, http:// www.jgi.doe.gov/) and in protostomes were also investigated using a similar search strategy using the human (Q96A98) and zebrafish (AAI64665) TIP39 sequences and the Fugu PTHrPA (Q9I8E9), PTHrPB (CAG26459), PTH1 (CAG26460) and PTH2 (CAG26461) and PTH-L (CAG26462) sequences.

\section{Sequence annotations and comparative analysis}

The deduced mature peptide sequences were obtained from BCM search launcher (http://searchlauncher.bcm. tmc.edu/seq-util) and the localisation of the putative signal peptide region predicted using SignalP (http://www.cbs. dtu.dk/services/SignalP). TM domain regions were deduced using TMHMM (http://www.cbs.dtu.dk/services/ TMHMM) and were manually edited according to the PRINTS annotation (http://www.bioinf.manchester.ac.uk/ 
dbbrowser/PRINTS/). Multiple sequence alignments of the amino acid sequence of chicken PTH/PTHrP receptors were performed using ClustalX [version 1.83 [60]] with the following parameters: Gonnet series matrix, Gap opening penalty 10, Gap extension 0.2. The alignments were displayed and manually edited and percentages of sequence similarity and identity calculated using GeneDoc [61]. Phylogenetic trees were constructed using the deduced amino acid sequences of the full-length receptor and were built with the maximum likelihood (PhyML 3.0) [62,63] and Distance methods using Neighbour Joining (BioNJ and Neighbour) [64]. A substitution JTT model gave the best fit for the protein dataset in PROTTEST and was used for phylogenetic tree construction [65]. Maximum likelihood analysis was performed with 500 bootstrap replicates with a discrete gamma distribution of rates among sites with 4 categories. Distance methods performed 1000 bootstrap replicates and ProtDist [66]. Both maximum likelihood (ML) and distance methods generated similar tree topologies. The human secretin receptor (HsaSCTR, AAA64949) was used as an out-group.

An unrooted phylogenetic tree of PTH-family members was also carried out using the deduced mature protein of the vertebrate genes. Consensus trees were constructed following a similar strategy to that described for the PTHRs and both maximum likelihood and distance methods generated similar tree topologies.

\section{Gene structure and gene linkage analysis}

Characterization of the chicken PTH/PTHrP receptor gene structures was performed on the basis of Ensembl gene predictions and by searching the genome with the nucleotide sequences of the mature receptor precursor using the NCBI Spidey interface (http://www.ncbi.nlm. nih.gov/spidey/). Intron-exon boundary splice sites (AG/ GT) were manually confirmed. The immediate gene environment of the chicken PTHRs was characterised using the NCBI genome chromosome annotations and compared with the homologue genome regions in Human, Xenopus and zebrafish and also with Ciona. The human and zebrafish gene environment was accessed via the NCBI Mapview (http://www.ncbi.nlm.nih.gov/mapview/) and the Xenopus and Ciona retrieved from Ensembl. Genes and gene order flanking PTHRs in the zebrafish and human genomes were confirmed using the Vertebrate Genome Annotation (VEGA) database (http://vega. sanger.ac.uk/). The gene environment of vertebrate TIP39 and PTH was also compared in lamprey, zebrafish, Xenopus and human using a similar strategy.

\section{Analysis of gene expression}

The methodology for production of cDNA from reverse transcription of total RNA and polymerase chain reaction (PCR) methodologies have been described by Pinheiro et al. [2]. The PTH1R PCR used primers PTH1Rfw atgggatcatatctggtttat and PTH1Rrv ggccagcagacaatacca with denaturation at $94^{\circ} \mathrm{C}$ for $3 \mathrm{~min}, 30$ cycles of $94^{\circ} \mathrm{C} 30 \mathrm{sec} ; 55^{\circ} \mathrm{C} 30 \mathrm{sec} ; 72^{\circ} \mathrm{C} 2 \mathrm{~min}$ and a final elongation step at $72^{\circ} \mathrm{C}$ for $10 \mathrm{~min}$. PTH3R was amplified using the primers PTH3Rfw atggggtctgtgggcagg and PTH3Rrv gttgaagtcgtagatgtagtc and 35 cycles with annealing at $57^{\circ} \mathrm{C}$. Since genome searches were negative for PTH2R and to confirm it was not a genome sequence gap, primers PTH2Rfw ${ }_{1}$ caaagtagttcatacacatataggagt, PTH2Rfw ${ }_{2}$ tgcctcacacatttactgg and PTH2Rrv ggactggctgctggtgct were designed using the conserved regions of known vertebrate sequences and PCR reactions were performed as for PTH1R using the same panel of tissues. The ribosomal subunit $18 \mathrm{~S}$ was used as reference gene with primers $18 \mathrm{Sfw}$ tcaagaacgaaagtcggagg and 18Srv ggacatctaagggcatcaca and 22 thermocycles in the same conditions as for PTH1R. The PCR products were analysed on $1.5 \%$ agarose gel and products sequenced to confirm identity.

\section{Expression vector constructs}

The complete coding regions, including the stop codon, of the chicken PTH1R and PTH3R were amplified from embryo limbs $(36 \mathrm{HH})$ cDNA with the primers PTH1Rfw atgggatcatatctggtttat and PTH1Rfinalrv ttacatcactgtctctcttc for PTH1R and PTH3Rfw atggggtctgtgggcagg and PTH3Rfinalrv tcatagcatcgtctccagct for PTH3R. Taq DNA proofreading polymerase (Advantage ${ }^{\circledR} 2$, polymerase mix, Clontech, France) was used in the PCR reactions according to the manufacturer's instructions with 10X Advantage 2 PCR Buffer, $0.2 \mathrm{mM}$ dNTP's (GE Healthcare, Spain) and $0.25 \mu \mathrm{M}$ of each specific primer for a final volume of $25 \mu \mathrm{l}$. The PCR reaction was carried out using the following thermocycle, $94^{\circ} \mathrm{C} 2 \mathrm{~min}, 30$ cycles of $94^{\circ} \mathrm{C} 30 \mathrm{sec}, 57^{\circ} \mathrm{C}$ for PTH1R and $59^{\circ} \mathrm{C}$ for PTH3R for $1 \mathrm{~min}, 72^{\circ} \mathrm{C}$ for $2 \mathrm{~min}$, followed by $72^{\circ} \mathrm{C}$ for $10 \mathrm{~min}$. The PCR products obtained were gel extracted using a GFX -PCR DNA and Gel Band Purification kit (Amersham Biosciences, Spain) and cloned into a pcDNA3.1/V5-His-TOPO expression vector (Invitrogen, USA) according to the manufacturer's instructions. The bacterial clones obtained were PCR screened using vector and receptor specific primers and colonies that contained the coding regions in frame with the promoter vector pCMV were selected and plasmid DNA was extracted using the DNA Midi-Prep kit (Roche, Germany). To facilitate receptor integration in the genome, approximately $5 \mu \mathrm{g}$ of the recombinant vectors were linearized with the restriction enzymes ApaI for PTH1R and BglII for PTH3R (Promega, Spain). The digested products were purified using phenol:clorophorm, ressuspended in $20 \mu \mathrm{l}$ of distilled DNAse-free water 
and $5 \mu \mathrm{l}$ was used to double transfect human embryonic kidney cell line 293 (HEK293 from European Collection of Cell Cultures; Salisbury, UK).

\section{Cell transfection and receptor stable cell line production} HEK293 cells were maintained in complete Dulbecco's modified Eagle's medium (DMEM, Sigma, Spain) with $4.5 \mathrm{~g} / \mathrm{L}$ glucose, $110 \mathrm{mg} / \mathrm{L}$ sodium pyruvate and Lglutamine supplemented with $10 \%$ sterile foetal bovine serum and $0.1 \%$ penicillin: streptomycin antibiotic mixture (10.000 U:10 mg/ml, Sigma) in a humid $5 \% \mathrm{CO}_{2}$ incubator (Sanyo) at $37^{\circ} \mathrm{C}$. On the day prior to transfection, $2-3 \times 10^{5}$ cells were seeded on 6 well-plates (Starsted, Portugal). Linearized constructs $(1 \mu \mathrm{g})$ and Fugene 6 (Roche, Germany) cell transfection reagent were used to transfect cells according to the manufactures protocol. The transfection complex was incubated for $40 \mathrm{~min}$ at room temperature before adding to the cells which were left to grown for 72 hours with daily changes of complete medium. Selection of the stably transfected clones was performed with complete medium supplemented with $800 \mu \mathrm{g} / \mathrm{ml}$ of Geneticin (G418 sulphate, GibcoBRL) and $250 \mu \mathrm{g} / \mathrm{ml}$ sterile filtered 1:100 amphotericin B solution (Sigma, Spain). Cell recovery was monitored daily by constant changes of antibiotic selective medium and the success of gene integration and expression was confirmed by RT-PCR with receptor specific primers.

\section{Receptor activation of CAMP}

The capacity of chicken (1-34) PTH-family peptides to activate the stably transfected PTH1R and PTH3R cell lines was analysed by measuring intracellular cAMP production. Cell line bearing chicken receptors PTH1R and PTH3R were assayed in triplicate in the same assay in 96 well plates (Starstedt). Three independent experiments were performed. Cells were incubated at $37^{\circ} \mathrm{C}$ in a $\mathrm{CO}_{2}$ incubator and two days prior to the experiments, $2-3 \times 10^{5}$ cells were plated and peptide assays were carried out by adding to the recombinant cells decreasing concentrations of test peptide: $100 \mathrm{nM}$ to $0.1 \mathrm{nM}$ of chicken PTH(1-34), PTHrP(1-34) and PTH-L(1-34) or $100 \mathrm{nM}$ of human PTH(1-34) and human TIP39 (Sigma, Spain). Prior to peptide addition, cells were incubated for $40 \mathrm{~min}$ with $1 \mathrm{mM}$ 3-isobutyl-1-methylxantine (IBMX, Sigma), which was replaced with fresh medium containing the test peptide in the presence of $1 \mathrm{mM}$ IBMX for a further $40 \mathrm{~min}$. Forskolin $(10 \mu \mathrm{M}$, Sigma) was used as positive control. Negative control assays were carried out using non-transfected cells in the presence or absence of $100 \mathrm{nM}$ of each peptide. At the end of the assays, cells were washed, ressuspended in $100 \mu \mathrm{l}$ of $1 \mathrm{x}$ PBS/0.5 M EDTA and immediately frozen at $-80^{\circ} \mathrm{C}$ to promote cell lysis for later quantification of intracellular cAMP production.

For quantification of intracellular cAMP, cells were lysed using 3 consecutive thaw $\left(42^{\circ} \mathrm{C}\right) /$ freeze $\left(-80^{\circ} \mathrm{C}\right)$ cycles and the supernatant and cell debris were sonicated for $20 \mathrm{sec}$ on ice. Cells were boiled at $100^{\circ} \mathrm{C}$ for $10 \mathrm{~min}$ to denature proteins and the supernatant was collected after centrifugation for $10 \mathrm{~min}$ at $4{ }^{\circ} \mathrm{C}$ and 19000 g. cAMP was quantified in duplicate by radioimmunoassay using the TRK432 kit (GE Healthcare, UK) following the manufacturer's instructions. Data was normalized by subtracting basal cAMP accumulation in the negative controls and production above basal levels per well (cAMP/well) was plotted against peptide concentration. cAMP was also quantified in HEK293 cells stably transfected with the pCMV-GFP (vector expressing green fluorescent protein) to confirm receptor expression and the results for cAMP accumulation were equivalent to the peptide assay negative controls indicating that the vector construct in the cells did not interfere with cAMP production.

\section{Receptor activation of intracellular $\mathrm{Ca}^{2+}$}

Intracellular $\mathrm{Ca}^{2+}\left(\mathrm{iCa}^{2+}\right)$ release was measured using the $\mathrm{Ca}^{2+}$ sensitive fluorescent dye Fluo-4 NW (Molecular Probes, Invitrogen) according to manufacturer's instructions. Prior to the assay, plates (96 well black/ plates, $\mu$ Clear bottom, Greiner, Germany) were treated with sterile poly-L-lysine $(0.1 \mathrm{mg} / \mathrm{ml}$, Sigma, Spain $)$ to avoid cell release. Approximately $1 \times 10^{5}$ cells in $100 \mu \mathrm{l}$ of selective medium were plated per well and allowed to attach for 2 days. Medium was removed and cells were washed once with $2.5 \mathrm{mM}$ probenecid (Molecular Probes, Invitrogen, Spain) in $1 \mathrm{x}$ PBS and incubated for $30 \mathrm{~min}$ at $37^{\circ} \mathrm{C}$ with $100 \mu \mathrm{l}$ of the Fluo-4 NW dye followed by an additional $30 \mathrm{~min}$ incubation period at room temperature. Incubations were carried out with $100 \mu \mathrm{l}$ of the different peptides concentrations (from $1 \mu \mathrm{M}$ to $100 \mathrm{nM}$ ) and cell fluorescence was measured every $10 \mathrm{sec}$ over 2 minutes after addition of reagent using a Synergy4 (Biotek, USA) plate reader. Carbachol (100 nM; Sigma, Spain) was used as a positive control for the assay and the background signal was determined by measuring fluorescence in wells containing nontransfected cells. An assay negative control was carried out using non-transfected cells incubated with $100 \mathrm{nM}$ peptide. Data was analysed by subtracting the background fluorescent values and plotted against peptide concentration.

\section{Statistics}

The results are presented as the mean \pm SEM of three independent experiments carried out in triplicate for 
cAMP experiments and two independent experiments carried out in quadruplicate for $\mathrm{Ca}^{2+}$ experiments. Data was plotted as the output of cAMP or $\mathrm{Ca}^{2+}$ at different peptide concentrations for each PTHR using SigmaPlot 9 (Systat, Inc., San Jose, CA). EC 50 and confidence limits were calculated using a sigmoidal curve fitting feature within the Single Ligand Binding routine of the Pharmacology module of Sigmaplot. Unfortunately, the commercial radioimmunoassay for cAMP was withdrawn from the market while the study was already advanced and it was not possible to find an equivalent assay for tests at higher peptide concentrations to ensure saturation was achieved for all peptides. To improve curve fitting the maximum empirical stimulation achieved for each receptor was assumed to be at $100 \mathrm{nM}$ for all assays and the curve fitted accordingly.

\section{Additional files}

Additional file 1: Nucleotide and deduced amino acid sequence of the chicken PTH1R. Deduced sequence for PTH1R is based upon EST data and PCR amplification. Primer localization is represented by horizontal arrows and the exons change by vertical arrows. The TM domains are represented by bound lines and signal peptide in italic and bold. Cysteine residues are circled and putative $\mathrm{N}$-glycosylation sites are boxed.

Additional file 2: Nucleotide and deduced amino acid sequence of the chicken PTH3R. Sequence deduced based upon EST data and PCR amplification. Primer localization is represented by horizontal arrows and the exons change by vertical arrows. The TM domains are represented by bound lines and signal peptide by in italic and bold. Cysteine residues are circles and putative $\mathrm{N}$-glycosylation sites are boxed.

Additional file 3: Comparison of the vertebrate TIP39 and PTH gene environments. Only homologue genes are represented with the exception of the zebrafish TIP39 gene environment to demonstrate the lack of gene synteny with other vertebrate homologue regions. Dashed boxes represent putative gene locus in lamprey.

Additional file 4: Accumulation of cAMP in HEK293 cells transfected with chicken PTH1R and PTH3R. Human PTH and TIP39 peptides were used at $10 \mathrm{nM}$ and $100 \mathrm{nM}$. Values represent means \pm SEM of a single experiment carried out in triplicate.

\section{Competing interests}

The authors declare no financial competing interests.

\section{Authors' contributions}

PLCP did the experimental work on chicken (database searches, cDNA isolation, PCR), analyzed results and wrote the initial draft of the manuscript; JCRC supervised the comparative and phylogenetic analysis, carried out the receptor functional analysis, and contributed to the writing; DMP contributed to the planning of the work, analysis of results and writing; AVMC devised the work, obtained funds, analysed results and contributed to the writing of the manuscript. All authors read and approved the final manuscript.

\section{Acknowledgements}

This research was funded by European Social Fund and the Portuguese National Science Foundation - project PTDC/CVT/66735/2006 and fellowship SFRH/BD/30881/2006 to PLCP - and Ceratonia prize (University of Algarve/ Caixa Geral de Depósitos). The authors acknowledge Elsa Couto for performing the CAMP radioimmunoassays.

Received: 20 February 2012 Accepted: 18 June 2012 Published: 6 July 2012

\section{References}

1. Guerreiro PM, Renfro JL, Power DM, Canario AVM: The parathyroid hormone family of peptides: structure, tissue distribution, regulation, and potential functional roles in calcium and phosphate balance in fish Am J Physiol Regul Integr Comp Physiol 2007, 292(2):R679-R696.

2. Pinheiro PL, Cardoso JC, Gomes AS, Fuentes J, Power DM, Canario AVM: Gene structure, transcripts and calciotropic effects of the PTH family of peptides in Xenopus and chicken. BMC Evol Biol 2010, 10(1):373.

3. Keutmann HT, Sauer MM, Hendy GN, O'Riordan LH, Potts JT Jr: Complete amino acid sequence of human parathyroid hormone. Biochemistry 1978, 17(26):5723-5729.

4. Moseley JM, Kubota M, Diefenbach-Jagger H, Wettenhall RE, Kemp BE, Suva LJ, Rodda CP, Ebeling PR, Hudson PJ, Zajac JD, et al: Parathyroid hormonerelated protein purified from a human lung cancer cell line. Proc Natl Acad Sci U S A 1987, 84(14):5048-5052.

5. Usdin TB, Wang T, Hoare SR, Mezey E, Palkovits M: New members of the parathyroid hormone/parathyroid hormone receptor family: the parathyroid hormone 2 receptor and tuberoinfundibular peptide of 39 residues. Front Neuroendocrinol 2000, 21(4):349-383.

6. Canario AVM, Rotllant J, Fuentes J, Guerreiro PM, Rita Teodosio H, Power DM, Clark MS: Novel bioactive parathyroid hormone and related peptides in teleost fish. Febs Lett 2006, 580(1):291-299.

7. Danks JA, Ho PM, Notini AJ, Katsis F, Hoffmann P, Kemp BE, Martin TJ, Zajac JD: Identification of a parathyroid hormone in the fish Fugu rubripes. J Bone Miner Res 2003, 18(7):1326-1331.

8. Gensure RC, Ponugoti B, Gunes Y, Papasani MR, Lanske B, Bastepe M, Rubin DA, Jüppner $\mathrm{H}$ : Identification and characterization of two parathyroid hormone-like molecules in zebrafish. Endocrinology 2004, 145(4):1634-1639.

9. Liu Y, Ibrahim AS, Tay BH, Richardson SJ, Bell J, Walker TI, Brenner S, Venkatesh B, Danks JA: Parathyroid hormone gene family in a cartilaginous fish, the elephant shark (Callorhinchus milii). J Bone Miner Res 2010, 25(12):2613-2623

10. Rubin DA, Jüppner $\mathrm{H}$ : Zebrafish express the common parathyroid hormone/parathyroid hormone-related peptide receptor (PTH1R) and a novel receptor (PTH3R) that is preferentially activated by mammalian and fugufish parathyroid hormone-related peptide. J Biol Chem 1999, 274(40):28185-28190.

11. Cardoso JC, Pinto VC, Vieira FA, Clark MS, Power DM: Evolution of secretin family GPCR members in the metazoa. BMC Evol Biol 2006, 6:108.

12. Clark MS, Thorne MA, Vieira FA, Cardoso JC, Power DM, Peck LS: Insights into shell deposition in the Antarctic bivalve Laternula elliptica: gene discovery in the mantle transcriptome using 454 pyrosequencing. BMC Genomics 2010, 11:362.

13. Gardella TJ, Jüppner H: Molecular properties of the PTH/PTHrP receptor. Trends Endocrinol Metab 2001, 12(5):210-217.

14. Jüppner $H$, Abou-Samra AB, Freeman M, Kong XF, Schipani $E$, Richards J, Kolakowski LF Jr, Hock J, Potts JT Jr, Kronenberg HM, et al: A G protein-linked receptor for parathyroid hormone and parathyroid hormone-related peptide. Science 1991, 254(5034):1024-1026.

15. Harmar AJ: Family-B G-protein-coupled receptors. Genome Biol 2001, 2(12). REVIEWS3013.

16. Zuscik MJ, O'Keefe RJ, Gunter TE, Puzas JE, Schwarz EM, Rosier RN: Parathyroid hormone-related peptide regulation of chick tibial growth plate chondrocyte maturation requires protein kinase A. J Orthop Res 2002, 20(5):1079-1090.

17. Li TF, Dong Y, lonescu AM, Rosier RN, Zuscik MJ, Schwarz EM, O'Keefe RJ, Drissi H: Parathyroid hormone-related peptide (PTHrP) inhibits Runx2 expression through the PKA signaling pathway. Exp Cell Res 2004, 299(1):128-136.

18. Abou-Samra AB, Jueppner $H$, Westerberg D, Potts JT Jr, Segre GV: Parathyroid hormone causes translocation of protein kinase-C from cytosol to membranes in rat osteosarcoma cells. Endocrinology 1989, 124(3):1107-1113.

19. Gensure RC, Gardella TJ, Jüppner H: Parathyroid hormone and parathyroid hormone-related peptide, and their receptors. Biochem Biophys Res Commun 2005, 328(3):666-678.

20. Gensure $\mathrm{R}$, Jüppner $\mathrm{H}$ : Parathyroid hormone without parathyroid glands. Endocrinology 2005, 146(2):544-546.

21. Papasani MR, Gensure RC, Yan YL, Gunes Y, Postlethwait JH, Ponugoti B, John MR, Jüppner $H$, Rubin DA: Identification and characterization of the 
zebrafish and fugu genes encoding tuberoinfundibular peptide 39 . Endocrinology 2004, 145(11):5294-5304.

22. Usdin TB, Hoare SR, Wang T, Mezey E, Kowalak JA: TIP39: a new neuropeptide and PTH2-receptor agonist from hypothalamus. Nat Neurosci 1999, 2(11):941-943.

23. Pliam NB, Nyiredy KO, Arnaud CD: Parathyroid hormone receptors in avian bone cells. Proc Natl Acad Sci U S A 1982, 79(6):2061-2063.

24. Forte $L R$, Langeluttig $S G$, Poelling RE, Thomas ML: Renal parathyroid hormone receptors in the chick: downregulation in secondary hyperparathyroid animal models. Am J Physiol 1982, 242(3):E154-163.

25. Zhao Q, Brauer PR, Xiao L, McGuire MH, Yee JA: Expression of parathyroid hormone-related peptide (PTHrP) and its receptor (PTH1R) during the histogenesis of cartilage and bone in the chicken mandibular process. J Anat 2002, 201(2):137-151.

26. lannotti JP, Brighton CT, lannotti V, Ohishi T: Mechanism of action of parathyroid hormone-induced proteoglycan synthesis in the growth plate chondrocyte. J Orthop Res 1990, 8(1):136-145.

27. Lagerstrom MC, Hellstrom AR, Gloriam DE, Larsson TP, Schioth HB, Fredriksson R: The G protein-coupled receptor subset of the chicken genome. PLoS Comput Biol 2006, 2(6)::54.

28. Bhattacharya P, Yan YL, Postlethwait J, Rubin DA: Evolution of the vertebrate pth2 (tip39) gene family and the regulation of PTH type 2 receptor (pth2r) and its endogenous ligand pth2 by hedgehog signaling in zebrafish development. J Endocrinol 2011, 211(2):187-200.

29. Jüppner H, Schipani E, Bringhurst FR, McClure I, Keutmann HT, Potts JT Jr, Kronenberg HM, Abou-Samra AB, Segre GV, Gardella TJ: The extracellular amino-terminal region of the parathyroid hormone (PTH)/PTH-related peptide receptor determines the binding affinity for carboxyl-terminal fragments of PTH-(1-34). Endocrinology 1994, 134(2):879-884.

30. Pioszak AA, Xu HE: Molecular recognition of parathyroid hormone by its $G$ protein-coupled receptor. Proc Natl Acad Sci U S A 2008, 105(13):5034-5039.

31. Gardella TJ, Jüppner H, Wilson AK, Keutmann HT, Abou-Samra AB, Segre GV, Bringhurst FR, Potts JT Jr, Nussbaum SR, Kronenberg HM: Determinants of [Arg2]PTH-(1-34) binding and signaling in the transmembrane region of the parathyroid hormone receptor. Endocrinology 1994, 135(3):1186-1194.

32. Lee C, Luck MD, Jüppner H, Potts JT Jr, Kronenberg HM, Gardella TJ: Homolog-scanning mutagenesis of the parathyroid hormone (PTH) receptor reveals PTH-(1-34) binding determinants in the third extracellular loop. Mol Endocrinol 1995, 9(10):1269-1278.

33. Kong XF, Schipani E, Lanske B, Joun $H$, Karperien M, Defize LH, Jüppner $H$, Potts JT Jr, Segre GV, Kronenberg HM, et al: The rat, mouse and human genes encoding the receptor for parathyroid hormone and parathyroid hormone-related peptide are highly homologous. Biochem Biophys Res Commun 1994, 200(3):1290-1299.

34. Schneider H, Feyen JH, Seuwen K, Movva NR: Cloning and functional expression of a human parathyroid hormone receptor. Eur $\mathrm{J}$ Pharmacol 1993, 246(2):149-155.

35. Usdin TB, Gruber C, Bonner TI: Identification and functional expression of a receptor selectively recognizing parathyroid hormone, the PTH2 receptor. J Biol Chem 1995, 270(26):15455-15458.

36. Hang XM, Power D, Flik G, Balment RJ: Measurement of PTHrP, PTHR1, and CaSR expression levels in tissues of sea bream (Sparus aurata) using quantitative PCR. Ann N Y Acad Sci 2005, 1040:340-344.

37. Rotllant J, Redruello B, Guerreiro PM, Fernandes H, Canario AVM, Power DM: Calcium mobilization from fish scales is mediated by parathyroid hormone related protein via the parathyroid hormone type 1 receptor. Regul Pept 2005, 132(1-3):33-40.

38. Torday JS, Ihida-Stansbury K, Rehan VK: Leptin stimulates Xenopus lung development: evolution in a dish. Evol Dev 2009, 11(2):219-224.

39. Bergwitz C, Klein P, Kohno H, Forman SA, Lee K, Rubin D, Jüppner H: Identification, functional characterization, and developmental expression of two nonallelic parathyroid hormone (PTH)/PTH-related peptide receptor isoforms in Xenopus laevis (Daudin). Endocrinology 1998, 139(2):723-732.

40. Rotllant J, Guerreiro PM, Anjos L, Redruello B, Canario AVM, Power DM: Stimulation of cortisol release by the $\mathrm{N}$ terminus of teleost parathyroid hormone-related protein in interrenal cells in vitro. Endocrinology 2005, 146(1):71-76.

41. Rotllant J, Guerreiro PM, Redruello B, Fernandes H, Apolonia L, Anjos L, Canario AVM, Power DM: Ligand binding and signalling pathways of PTH receptors in sea bream (Sparus auratus) enterocytes. Cell Tissue Res 2006, 323(2):333-341.
42. Cormier S, Delezoide AL, Benoist-Lasselin C, Legeai-Mallet L, Bonaventure J, Silve C: Parathyroid hormone receptor type $1 /$ Indian hedgehog expression is preserved in the growth plate of human fetuses affected with fibroblast growth factor receptor type 3 activating mutations. Am J Pathol 2002, 161(4):1325-1335.

43. Jüppner H: Role of parathyroid hormone-related peptide and Indian hedgehog in skeletal development. Pediatr Nephrol 2000, 14(7):606-611.

44. Hirai T, Chagin AS, Kobayashi T, Mackem S, Kronenberg HM: Parathyroid hormone/parathyroid hormone-related protein receptor signaling is required for maintenance of the growth plate in postnatal life. Proc Natl Acad Sci U S A 2011, 108(1):191-196.

45. Jüppner $\mathrm{H}$ : Receptors for parathyroid hormone and parathyroid hormone-related peptide: exploration of their biological importance. Bone 1999, 25(1):87-90.

46. Atwood BK, Lopez J, Wager-Miller J, Mackie K, Straiker A: Expression of G protein-coupled receptors and related proteins in HEK293, AtT20, BV2, and $\mathrm{N} 18$ cell lines as revealed by microarray analysis. BMC Genomics 2011, 12:14.

47. Couvineau A, Laburthe M: The family B1 GPCR: Structural aspects and interaction with accessory proteins. Curr Drug Targets 2011.

48. Torday JS, Rehan VK: Cell-cell signaling drives the evolution of complex traits: introduction--lung evo-devo. Integr Comp Biol 2009, icp017.

49. Paine CT, Paine ML, Luo W, Okamoto CT, Lyngstadaas SP, Snead ML: A Tuftelin-interacting protein (TIP39) localizes to the apical secretory pole of mouse ameloblasts. J Biol Chem 2000, 275(29):22284-22292.

50. Hull KL, Fathimani K, Sharma P, Harvey S: Calcitropic peptides: neural perspectives. Comp Biochem Physiol 1998, 119(3):389-410.

51. Wendelaar Bonga SE, Lafeber FP, Flik G, Kaneko T, Pang PK: Immunocytochemical demonstration of a novel system of neuroendocrine peptidergic neurons in the pond snail Lymnaea stagnalis, with antisera to the teleostean hormone hypocalcin and mammalian parathyroid hormone. Gen Comp Endocrinol 1989, 75(1):29-38,

52. Hull K, Marler R, Harvey S: Neural calcitropic peptides: immunoreactive characterization in fish and invertebrates. Neurosci Lett 2006, 404(1-2):15-19.

53. Cardoso JC, Vieira FA, Gomes AS, Power DM: The serendipitous origin of chordate secretin peptide family members. BMC Evol Biol 2010, 10:135.

54. Ohno S: Evolution by gene duplication. New York: Springer; 1970.

55. Dehal P, Boore $\mathrm{J}$ : Two rounds of whole genome duplication in the ancestral vertebrate. PLoS Biol 2005, 3(10):e314.

56. Hurles M: Gene duplication: the genomic trade in spare parts. PLOS Biol 2004, 2(7):E206.

57. Kaessmann H: Origins, evolution, and phenotypic impact of new genes. Genome Res 2010, 20(10):1313-1326.

58. Hamburger $\mathrm{V}$, Hamilton HL: A series of normal stages in the development of the chick embryo, (Reprinted from J Morph, Vol 88, 1951). Dev Dyn 1992, 195(4):231-272.

59. Altschul SF, Gish W, Miller W, Myers EW, Lipman DJ: Basic local alignment search tool. J Mol Biol 1990, 215(3):403-410.

60. Thompson JD, Gibson TJ, Plewniak F, Jeanmougin F, Higgins DG: The CLUSTAL_X windows interface: flexible strategies for multiple sequence alignment aided by quality analysis tools. Nucleic Acids Res 1997, 25(24):4876-4882.

61. Nicholas KB Jr, Deerfield DWI, NHB: GeneDoc: Analysis and visualization of genetic variation. In.: EMBNEW.NEWS. 4th edition. 1997:14.

62. Guindon S, Gascuel O: A simple, fast, and accurate algorithm to estimate large phylogenies by maximum likelihood. Syst Biol 2003, 52(5):696-704.

63. Guindon S, Dufayard JF, Lefort V, Anisimova M, Hordijk W, Gascuel O: New algorithms and methods to estimate maximum-likelihood phylogenies: assessing the performance of PhyML 3.0. Syst Biol 2010, 59(3):307-321.

64. Saitou N, Nei M: The neighbor-joining method: a new method for reconstructing phylogenetic trees. Mol Biol Evol 1987, 4(4):406-425.

65. Abascal F, Zardoya R, Posada D: ProtTest: selection of best-fit models of protein evolution. Bioinformatics 2005, 21(9):2104-2105.

66. Felsenstein J: Confidence limits on phylogenies: An approach using the bootstrap. Evolution 1985, 39:783-791.

doi:10.1186/1471-2148-12-110

Cite this article as: Pinheiro et al.: Functional characterization and evolution of PTH/PTHrP receptors: insights from the chicken. BMC Evolutionary Biology 2012 12:110. 